\title{
The Effect and Mechanism of Trade Liberalization on Wage
}

\author{
Xiaofang Zhang ${ }^{1} \&$ Fei Yang ${ }^{2}$ \\ ${ }^{1}$ School of International Trade and Economics, Central University of Finance and Economics, P. R. China \\ ${ }^{2}$ School of Economics, Peking University, P. R. China \\ Correspondence: Xiaofang Zhang, School of International Trade and Economics, Central University of Finance \\ and Economics, Beijing 100081, P. R. China. E-mail: zhxf25@foxmail.com
}

Received: April 9, 2019

doi:10.5539/ijbm.v15n5p184

\author{
Accepted: April 25, 2020 \\ Online Published: April 27, 2020 \\ URL: https://doi.org/10.5539/ijbm.v15n5p184
}

\begin{abstract}
This research discussed the relationship and mechanism between trade liberalization and the wage level of enterprises. Using the firm-level data from Annual Survey of Industrial Firms(ASIF) database and tariff data from World Bank, we find that, the final goods trade liberalization will reduce the wage, while the intermediate goods trade liberalization will improve the level of enterprises' wages. And that trade liberalization affects wages through firm performance. The reduction of input tariff reduces firm's input cost, and increases firm's sales and profit, then the firm has more ability to provide higher wages. While the decline of output tariff damages firm's performance, which leads enterprises to transfer the loss by reducing wages.
\end{abstract}

Keywords: trade liberalization, wage, intermediary effect

\section{Introduction}

In the late 1970s, China formulated the economic development policy of reform and opening up, and began to participate in the economic process of other countries and regions in the world. In the 1990s, China actively prepared to join the World Trade Organization (WTO), began to unilaterally reduce tariff and non-tariff barriers, and gave more and more enterprises the right of direct trade. After China's formal accession to the WTO in December 2001, it further cut tariffs. By 2018, China's weighted average tariff rate was as low as $4.4 \%$.

With the deepening of trade liberalization, China's personal income gap, regional income gap, and urban-rural income gap are getting worse. The 2018 report on China's labor market development issued by Beijing Normal University shows that there are significant differences in the balance of China's regional labor market. Due to the segmentation of the labor market and other factors, it is difficult to realize the law of one price in the labor market. The wage differences between urban and rural areas, regions and industries are very obvious, and the income gap is at a high level.

\section{Literature Review}

Revenga (1992) studied the impact of import competition on the wage level of the manufacturing industry in the United States, and found that the change in the price of imported goods had a significant impact on the wage level of the manufacturing industry. Milner and Wright (1998) studied the wage changes in Mauritius during the process of trade liberalization, which showed that trade liberalization improved the average wage level in the long term. The study of Chile by Ferreira and Lithchfield (1999) and Levinson (1999) found that while trade liberalization increased the long-term average wage level, the country's employment decreased. Acharya (2015) found that Canada's wage level was significantly affected by total imports, but the response of wage level to bilateral import liberalization was quite different. Import from China was negatively related to its wage level, while import from Mexico was positively related to its wage level. Helpman (2010) built a theoretical model based on Melitz (2003) to study the impact of trade liberalization on wages. The analysis shows that the higher the productivity of enterprises, the higher the wages paid. Under the condition of given productivity, exports can further improve the wages paid by enterprises, so international trade will aggravate the wage inequality of exporting countries.

According to the research of Bernard et al. (2007), Verhoogen (2008), Gibson and Stillman (2009), if larger enterprises pay higher wages, then when enterprises have more labor and production resources to expand production and sales, they will pay higher wages. Brandt et al. (2017) pointed out that trade liberalization will 
have an impact on the performance of Chinese enterprises. Amiti and Davis (2012) pointed out that the growth of enterprise performance makes enterprises more capable and motivated to expand production, thus bringing higher wages.

\section{Methodology}

\subsection{Economic Model}

To study the effect of trade liberalization on wage, we build the benchmark regression model as follows:

$$
\text { lnwage }_{i j t}=\alpha+\beta_{1} \text { outputariff }_{j t}+\beta_{2} \text { inputariff }_{j t}+\beta_{3} X_{i t}+v_{i}+\gamma_{t}+\varepsilon_{i t}
$$

Where, wage $_{i j t}$ represents the average wage of firm i in industry $\mathrm{j}$ in year $\mathrm{t}$, outputariff $f_{j t}$ and inputariff $f_{j t}$ represent the output tariff and input tariff of industry $\mathrm{j}$ in year t respectively, and the control variable $X_{i t}$ includes the total factor productivity (tfp_lp), markup, the firm size represented by the enterprise sales volume (size), the firm age, the Per capita intermediate input (inputpc), these variables all change with time. In addition, the firm fixed effect $v_{i}$ and time fixed effect $\gamma_{t}$ are also controlled in the model to control the characteristics of the firm not changing with time and the different impacts faced by the firm in different years.

\subsection{Data}

This paper mainly uses two sets of large panel data: production data and tariff data at the enterprise level. At the same time, the key variables involved in the empirical analysis include: the output tariff (outputtariff) and the input tariff (inputtariff), total factor productivity (TFP), and markup. In this part, we introduce the data used in this paper and the measurement method of key variables in detail

\subsubsection{Firm-Level Data}

The firm-level production data used in this paper is the Annual Survey of Industrial Firms(ASIF) in 2000-2007 conducted by the National Bureau of Statistics of China, which includes all state-owned enterprises and non-state-owned enterprises with annual income of more than RMB 5 million. This data includes three complete accounting statements: profit and loss statement, balance sheet and cash flow statement, reporting nearly 190 indicators such as firm name, firm code, firm location, registration type, capital structure, number of employees, wages and benefits expenditure, income, export and so on. On average, the annual GDP of these enterprises covered by ASIF accounts for about $95 \%$ of China's industrial GDP.

First of all, according to the provisions of " Generally Accepted Accounting Principles" (GAAP), we adopt the processing method of Cai-Liu (2009) and Feenstra-Li-Yu (2011) to exclude observations if they meet any of the following criteria: (1) the enterprise with liquid assets greater than total assets; (2) the enterprise with total fixed assets greater than total assets; (3) the enterprise with net fixed assets greater than total assets ; (4) enterprises with an invalid time of establishment (for example, the year of opening is less than the reporting year, the month of opening is more than 12 or less than 1); (5) enterprises with less than 8 employees; (6) non-state-owned enterprises with total industrial sales value less than 5 million. After preliminary processing, the number of valid samples included in the data decreased from 1.9 million to 1.8 million.

Secondly, there are many enterprises sharing the same firm name or firm code in the annual survey database of industrial firms, and there are also cases of changing the firm name due to restructuring, reorganization, or expansion. In addition, there are many cases of "province (city, county)", blank space, and various symbols in the statistics. All of the above make it difficult to build a panel data with firm ID and year as dimensions. This paper uses the method in Brandt et al (2012) to identify whether different samples come from the same firm by using the information of firm ID, firm name, legal representative name, telephone, zip code, address, industry code, main product name, establishment time, etc. After the cross-matching, about $10 \%$ of the observations (about 200000) belong to the same name but different or opposite legal codes. Obviously, if we ignore the matching problem, it will seriously affect the authenticity and accuracy of the samples. Table 1 reports the summary statistics of key variables. 
Table 1. Summary statistics

\begin{tabular}{|c|c|c|c|c|c|}
\hline Variable & Obs & Mean & Std. Dev. & Min & Max \\
\hline Wage & $1,628,990$ & 2454.34 & 14291.20 & 0 & $1.73 \mathrm{E}+07$ \\
\hline Outputtariff & 808,588 & 12.48 & 7.80 & 0.00 & 120.24 \\
\hline Inputtariff & $1,198,612$ & 8.10 & 3.52 & 0.86 & 32.38 \\
\hline Tfp_Lp & $1,596,412$ & 6.04 & 1.00 & 2.85 & 8.57 \\
\hline Markup & 718,104 & 1.05 & 13.93 & -281.65 & 15330 \\
\hline Inputpc & $1,628,990$ & 220.02 & 434.86 & 0.00 & 76657.35 \\
\hline Size & $1,628,990$ & 42399.72 & 89700.19 & 0.00 & 8326390 \\
\hline Age & $1,628,990$ & 10.87 & 12.36 & 0.00 & 813 \\
\hline
\end{tabular}

\subsubsection{Tariff Data}

The tariff data used in this paper is from HS 6-digit level tariff data of the WITS database of the World Bank. During the statistical period, the HS product code has been adjusted. According to the code comparison table of different versions of the World Customs Organization (WCO), we changed the different hs code to hs2002. Then, we use the method of Brandt et al (2017) to map the hs2002 code of the original tariff data to the national economic industry classification (CIC-4) of GB / t4754-2002, and get the output tariffs at the 4-digit level of CIC. To avoid any bias in the industry average due to low trade volumes in heavily protected product lines, we use an unweighted average.

The input tariffs are a weighted average of output tariffs. The calculation method is the same as Brandt et al (2017):

$$
\text { inputtariff } f_{i t}=\sum_{g \in G_{i}} \alpha_{g t} \cdot \text { outputtariff } f_{g t}
$$

Among which, i、t、g represent industry, year and input factors respectively. $G_{i}$ represents the input factors set of industry $\mathrm{i}$, and $a_{g t}$ represents the input proportion of factor $\mathrm{g}$. The calculation method of $a_{g t}$ is the input cost of factor $g$ divided by the input cost of all factors in industry $\mathrm{i}$ :

$$
a_{g t}=\text { input }_{g t} / \sum_{g \in G_{i}} \text { input }_{g t}
$$

The proportion of input $\left(a_{g t}\right)$ can be calculated by using China's 2002 input-output table.

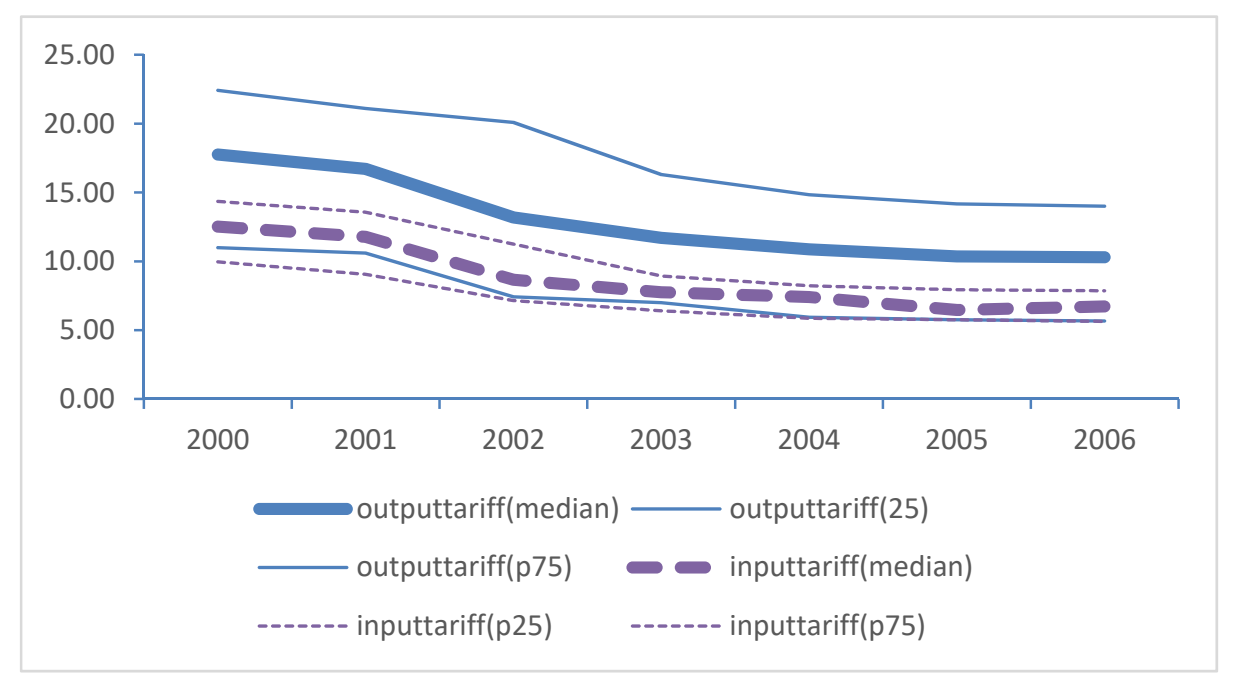

Figure 1. The trend of output tariff and input tariff

\subsubsection{TFP and Markup}

Economists often calculate TFP by using OLS, OP method in Olley and Pakes (1996), and LP method in Levinsohn and Petrin (2005). Because of the problems of simultaneity and selection, the results of OLS 
estimation are biased. OP and LP methods obviously improve the bias of OLS results, and will be more accurate to reflect the productivity of enterprises. Besides, LP method uses intermediate inputs instead of investment as proxy variable, which can correct some defects of OP method itself. But the results of OP method and LP method have not much difference. So we use LP method to calculate total factor productivity in this paper.

Markup refers to the deviation of the product price from its marginal cost, or the difference between the product price and its marginal cost. Markup is usually used to measure the monopoly power and trade gains of enterprises in the market, and to describe the market structure. According to the definition of markup, the most intuitive calculation method is:

$$
\text { markup }=\frac{\text { sales }}{\text { sales-profit }}
$$

Where sales and profit represent the sales and profit of the enterprise respectively.

\section{Results}

\subsection{Basic Results}

Table 2 reports the regression results of the benchmark model. where, the first column only controls the total factor productivity, markup, firm fixed effect and, time fixed effect of the enterprise. The regression coefficient of the output tariff is positive, which indicates that the trade liberalization of the final product leads to the decline of the wage level, while the decline of the intermediate product tariff will lead to the rise of the wage level. In the second column, the control variables related to enterprise characteristics are added, and the regression results also show that the wage level is positively related to output tariff level, and negatively related to the input tariff level.

Table 2. the benchmark regression results of the impact of trade liberalization on wages

\begin{tabular}{|c|c|c|}
\hline & $\begin{array}{c}(1) \\
\text { lnwage }\end{array}$ & $\begin{array}{c}(2) \\
\text { lnwage }\end{array}$ \\
\hline \multirow[t]{2}{*}{ lnoutputtariff } & $0.0589^{* * *}$ & $0.0690^{* * *}$ \\
\hline & $(62.81)$ & $(73.95)$ \\
\hline \multirow[t]{2}{*}{ lninputtariff } & $-0.0572^{* * *}$ & $-0.0656^{* * *}$ \\
\hline & $(-46.82)$ & $(-53.74)$ \\
\hline \multirow[t]{2}{*}{ tfp_lp } & $0.115^{* * *}$ & $0.0704^{* * *}$ \\
\hline & (176.98) & (79.27) \\
\hline \multirow[t]{2}{*}{ markup } & $0.175^{* * *}$ & $0.0985^{* * *}$ \\
\hline & (31.44) & $(17.87)$ \\
\hline \multirow[t]{2}{*}{ lninputpc } & & $0.186^{* * *}$ \\
\hline & & (210.73) \\
\hline \multirow[t]{2}{*}{ lnsize } & & $-0.0334^{* * *}$ \\
\hline & & $(-32.87)$ \\
\hline \multirow[t]{2}{*}{ lnage } & & $0.00533^{* * *}$ \\
\hline & & $(8.60)$ \\
\hline \multirow[t]{2}{*}{ _cons } & $0.999^{* * *}$ & $0.842^{* * *}$ \\
\hline & (160.84) & (105.05) \\
\hline Firm FE & Yes & Yes \\
\hline Year FE & Yes & Yes \\
\hline$N$ & 1595685 & 1546148 \\
\hline $\mathrm{R} 2$ & 0.619 & 0.619 \\
\hline
\end{tabular}

Notes. $* \mathrm{p}<0.1, * * \mathrm{p}<0.05, * * * \mathrm{p}<0.01, \mathrm{t}$-value in brackets.

\subsection{Robustness Checks}

We conduct two checks to ensure that our baseline results are robust to alternative schemes. First, we use the TFP measured by OP method to instead that by LP method, and recalculate the markup using the method in De Loecker (2012). Column (1) and (2) of table 3 report the results. Secondly, we use one-period lag tariff as the explanatory variable to check the basic model. And Column (3) of table 3 report the results. All the robustness checks does not qualitatively change the baseline results. 
Table 3. Robustness checks results

\begin{tabular}{lccc}
\hline & $(1)$ & $(2)$ & $(3)$ \\
& lnwage & lnwage & $0.0635^{* * *}$ \\
\hline lnoutputtariff & $0.0606^{* * *}$ & $0.0698^{* * * *}$ & $(57.81)$ \\
& $(65.03)$ & $(75.28)$ & $-0.0594^{* * *}$ \\
Ininputtariff & $-0.0549^{* * *}$ & $-0.0638^{* * *}$ & $(-41.20)$ \\
& $(-45.23)$ & $(-52.64)$ & $0.0704^{* * *}$ \\
tfp_op & $0.120^{* * *}$ & $0.0763^{* * *}$ & $(63.47)$ \\
& $(190.12)$ & $(90.24)$ & $0.000112^{* * *}$ \\
markup & $0.194^{* * *}$ & $0.103^{* * *}$ & $(6.06)$ \\
& $(35.53)$ & $(19.04)$ & $0.158^{* * *}$ \\
lninputpc & & $0.185^{* * *}$ & $(130.48)$ \\
& & $(212.68)$ & $-0.0163^{* * *}$ \\
lnsize & & $-0.0356^{* * *}$ & $(-12.43)$ \\
lnage & & $(-35.97)$ & 0.000505 \\
& & $0.00225^{* * *}$ & $(0.62)$ \\
cons & & $(3.66)$ & $0.918^{* * *}$ \\
Firm FE & & $0.806^{* * *}$ & $(115.32)$ \\
Year FE & $(147.28)$ & $(103.76)$ & Yes \\
$N$ R2 & Yes & Yes & Yes \\
\hline
\end{tabular}

Notes. ${ }^{*} \mathrm{p}<0.1,{ }^{* *} \mathrm{p}<0.05,{ }^{* * *} \mathrm{p}<0.01, \mathrm{t}$-value in brackets.

\subsection{Endogeneity}

There are endogenous problems between tariffs and wages caused by reverse causality and missing variables. Considering that the general and substantial decrease of tariffs after China's accession to the WTO provides us with excellent natural experimental conditions, we use the impact of China's accession to the WTO and the difference-in-difference model to check the endogenous problem between tariffs and wages. The specification is set as follow:

$$
\operatorname{lnw}_{i j t}=\alpha+\beta_{1} \text { tariff }_{j 2001} * \text { post } 02_{t}+\beta_{2} \operatorname{tariff}_{j 2001}+\beta_{3} \text { post } 02_{t}+\beta_{4} X_{i t}+v_{i}+\gamma_{t}+\varepsilon_{i t}
$$

Where, tariff $_{j 2001}$ represents respectively the output tariff and input tariff of industry $\mathrm{j}$ in 2001 , post $02_{t}$ represents the dummy variable of whether China joined the WTO in year $t$, and its value is 1 if China has joined the WTO, otherwise its value is 0 . The control variables $X_{i t}$ is the same as that in the basic model. The focus of our DID strategy is the coefficients of the interaction terms in the regression: $\beta_{1}$, which represent the average treatment effects of the treatment group and the control group before and after China's accession to WTO. The sign of the interaction terms coefficient estimates help us to understand the impact of tariff reduction on wages. We cluster the standard errors at the province-year level to adjust for the correlation within each group. 
Table 4. endogeneity checks results

\begin{tabular}{ccc}
\hline & $(1)$ & $(2)$ \\
& Output tariff & Input tariff \\
\hline post02\#tariff2001 & $-0.0667^{* * *}$ & $0.0147^{* * *}$ \\
& $(-47.85)$ & $(8.60)$ \\
Ininputpc & $0.209^{* * *}$ & $0.207^{* * *}$ \\
& $(117.83)$ & $(116.88)$ \\
lnsize & $-0.0484^{* * *}$ & $-0.0509^{* * *}$ \\
& $(-26.81)$ & $(-27.99)$ \\
Inage & $-0.00428^{* * *}$ & $-0.00196^{* *}$ \\
& $(-4.24)$ & $(-1.93)$ \\
tfp_lp & $0.0860^{* * *}$ & $0.0869^{* * *}$ \\
& $(62.18)$ & $(62.70)$ \\
cons & $1.072^{* * *}$ & $0.967^{* * *}$ \\
& $(98.10)$ & $(87.35)$ \\
Firm FE & Yes & Yes \\
Year FE & Yes & Yes \\
$N$ & 863133 & 863133 \\
adj. $R^{2}$ & 0.247 & 0.237 \\
\hline
\end{tabular}

Notes. $* \mathrm{p}<0.1, * * \mathrm{p}<0.05, * * * \mathrm{p}<0.01, \mathrm{t}$-value in brackets.

Table 4 reports the impact of intermediate goods and final goods tariff on wages after China's accession to the WTO. We can see from the results that the coefficient of the interaction terms between WTO and input tariff is positive, which indicates that the entry of WTO makes the intermediate goods tariff decrease and the wage level of the industry increase. However, the coefficient of the interaction term between the output tariff and WTO is negative, which shows that the competition brought by a sharp decline of the final product tariff after China's accession makes enterprises start to cut wages to transfer their losses.

\section{Mechanism}

Brandt et al. (2017) pointed out that trade liberalization will have an impact on the performance of Chinese enterprises. Amiti and Davis (2012) pointed out that the growth of enterprise performance makes enterprises more able to expand production, thus bringing more jobs and higher wages. Therefore, this paper takes the sales revenue and profit of enterprises as the agent variables of enterprise performance, to test the mechanism of the impact of trade liberalization on the wages of the labor market through the intermediary effect.

To test whether trade liberalization affects labor market through enterprise performance, we need to carry out the following three steps: (1) trade liberalization has a significant impact on labor wages; (2) trade liberalization has a significant impact on enterprise performance; (3) add enterprise performance into the basic model of trade liberalization and wages, and the estimations of the coefficient of tariff will be smaller than that of benchmark regression. We have carried out the first step in baseline regression, and the results show that the output tariff reduction will have a significant negative impact on wage, while the input tariff reduction will have a significant positive impact on wage. Next, we will check the second and third steps.

\subsection{Trade Liberalization and Firm Performance}

We build a model of trade liberalization and enterprise benefits to test whether the reduction of output tariff (input tariff) can make enterprises obtain higher (lower) enterprise benefits. The function is as follows:

$$
y_{i j t}=\alpha+\beta_{1} \text { tariff }_{j t}+\beta_{2} X_{i t}+v_{i}+\gamma_{t}+\varepsilon_{i t}
$$

where, $y_{i j t}$ represents the firm performance(profit or sales) in industry $\mathrm{j}$ in year t. tariff $f_{j t}$ represents the output tariff and input tariff, and the control variable $X_{i t}$ includes the TFP, enterprise age (age), per capita intermediate input (inputpc) and other variables that change with time. In addition, $v_{i}$ represents the firm fixed effect, and $\gamma_{t}$ represents the year fixed effect. 
Table 5. the effect of trade liberalization on firm performance

\begin{tabular}{ccccc}
\hline & $(1)$ & $(2)$ & $(3)$ & $(4)$ \\
\hline & \multicolumn{2}{c}{ Input tariff } & & Output tariff \\
\hline profit & $-0.00723^{* * *}$ & $-0.0105^{* * *}$ & $0.0369^{* * *}$ & sales \\
\hline Intariff & $(-2.83)$ & $(-11.50)$ & $(18.91)$ & $0.00108^{* *}$ \\
& $0.829^{* * *}$ & $0.519^{* * *}$ & $0.829^{* * *}$ & $(2.52)$ \\
tfp_lp & $(354.24)$ & $(507.04)$ & $(354.42)$ & $0.519^{* * *}$ \\
& $0.238^{* * *}$ & $0.345^{* * *}$ & $0.239^{* * *}$ & $(506.71)$ \\
Ininputpc & $(115.41)$ & $(272.03)$ & $(115.76)$ & $0.345^{* * *}$ \\
& $-0.0225^{* * *}$ & $0.0753^{* * *}$ & $-0.0235^{* * *}$ & $(271.84)$ \\
lnage & $(-11.10)$ & $(101.69)$ & $(-11.64)$ & $0.0752^{* * *}$ \\
& $-0.264^{* * *}$ & $4.755^{* * *}$ & $-0.263^{* * *}$ & $(101.44)$ \\
cons & $(-17.65)$ & $(738.44)$ & $(-17.62)$ & $4.757^{* * *}$ \\
& Yes & Yes & Yes & $(738.62)$ \\
Firm FE & Yes & Yes & Yes & Yes \\
Year FE & 1215906 & 1546848 & 1215906 & 1546848 \\
$N$ & 0.375 & 0.646 & 0.257 & 0.624 \\
adj. $R^{2}$ & & & & es \\
\hline
\end{tabular}

Notes. $* \mathrm{p}<0.1,{ }^{* *} \mathrm{p}<0.05, * * * \mathrm{p}<0.01, \mathrm{t}$-value in brackets.

Column (1) and (2) of Table 5 report the results of intermediate goods trade liberalization on firm profit and sales. It can be seen from the results that the estimation of the coefficient of input tariff is negative, and significant at the level of $1 \%$, no matter the performance of enterprises is measured by sales or profit. This shows that the intermediate goods trade liberalization will have a positive impact on firm performance, and the reduction of intermediate goods tariff significantly improves the sales and profit of enterprises.

Column (3) and (4) of Table 5 report the results of output tariff on firm profit and sales. The estimation of the coefficient of output tariff is positive, and significant at the level of $1 \%$ and $5 \%$ respectively, That means, different from the input tariff, the final goods trade liberalization will damage the firm performance, it will significantly reduce the sales and profit of enterprises.

\subsection{Trade Liberalization, Firm Performance and Wage}

we add firm performance into the benchmark model of trade liberalization and wages to verify whether the addition of firm performance variables will affect the estimation of the tariff coefficient. The function is set as follows:

$$
\text { lnwage }_{i t}=\alpha+\beta_{1} \text { inputtarif }_{j t}+\beta_{2} \text { outputtariff } f_{j t}+\beta_{3} y_{i t}+\beta_{4} X_{i t}+v_{i}+\gamma_{t}+\varepsilon_{i t}
$$

Column (1) of table 6 reports the regression results of trade liberalization on wages after the profit of enterprises is added. We can see that the estimation of input and output tariff coefficient are smaller than that in column (2) of Table 2, which means that trade liberalization affects labor wages through firm profit. The decrease of output tariff reduces the firm profits, and then reduces the wage level of enterprises, while the decrease of input tariff increases the profits, and then improves the wages of enterprises. 
Table 6. trade liberalization, firm performance and wage

\begin{tabular}{ccc}
\hline & $(1)$ & $(2)$ \\
& profit & sales \\
\hline Inperformance & $0.0287^{* * *}$ & $0.0268^{* * *}$ \\
& $(46.12)$ & $(47.44)$ \\
Ininputtariff & $-0.0141^{* * *}$ & $-0.0178^{* * *}$ \\
& $(-31.67)$ & $(-48.47)$ \\
lnoutputtariff & $0.0211^{* * *}$ & $0.0254^{* * *}$ \\
& $(67.65)$ & $(34.35)$ \\
tfp_lp & $0.0799^{* * *}$ & $0.0799^{* * *}$ \\
& $(68.37)$ & $(68.36)$ \\
lninputpc & $0.168^{* * *}$ & $0.168^{* * *}$ \\
& $(143.02)$ & $(143.02)$ \\
lnsize & $-0.0485^{* * *}$ & $-0.0486^{* * *}$ \\
& $(-37.05)$ & $(-37.06)$ \\
Inage & $0.0259^{* * *}$ & $0.0259^{* * *}$ \\
& $(34.41)$ & $(34.43)$ \\
cons & $1.077^{* * *}$ & $1.077^{* * *}$ \\
& $(133.19)$ & $(134.19)$ \\
Firm FE & Yes & Yes \\
Year FE & Yes & Yes \\
$N$ & 1215906 & 1215906 \\
adj. $R^{2}$ & 0.224 & 0.224 \\
\hline
\end{tabular}

Notes. $* \mathrm{p}<0.1,{ }^{* *} \mathrm{p}<0.05,{ }^{* * *} \mathrm{p}<0.01, \mathrm{t}$-value in brackets.

Column (2) of table 6 reports the results of trade liberalization on wages after adding the variable of firm sales. Similarly, we compare the coefficient of tariff in column (2) with that in column (2) of Table 2, and find that the coefficient of tariff on output and input tariff decreases significantly after the sales is added, which shows that trade liberalization also affects the wage level of enterprises through firm performance.

\section{Conclusion}

This research discussed the relationship and mechanism between trade liberalization and the wage level of enterprises. Using the firm-level data from Annual Survey of Industrial Firms (ASIF) database and tariff data from World Bank, we find: first, trade liberalization will have a significant impact on wages. The reduction of final product tariffs will reduce the wage level of enterprises, while the reduction of intermediate product tariffs will improve the level of enterprises' wages. Second, trade liberalization affects wages through firm performance. The import competition effect of the intermediate goods trade liberalization reduces the price of the product market, then input cost of the intermediate goods of the enterprise drops, which increases the markup of the enterprise, and has a positive impact on the profit and sales of the enterprise. So the enterprise has more ability to expand production and provide higher wage level. On the contrary, the decline of final product tariff makes enterprises facing more brutal competition. The reduction of commodity price damages their overall sales and profits. Enterprises transfer the impact by reducing wages.

\section{References}

Acharya, C. (2015). Impact of trade on Canada's employment, skill and wage structure. https://doi.org/10.1111/twec. 12360

Amiti, M., \& Davis, D. R. (2012). Trade and wages: Theory and evidence. Review of Economic Studies, 79(1), 1-36. https://doi.org/10.1093/restud/rdr016

Autor, D. H., Dorn, D., \& Hanson, G. H. (2013). The China Syndrome: Local Labor Market Effects of Import Competition in the United States. American Economic Review, 103(6), 2121-1268. https://doi.org/10.1257/aer.103.6.2121

Bernard, A. B., Jensen, P., \& Schott, K. (2007). Survival of the best fit: Exposure to low-wage countries and the uneven growth of US manufacturing plants. Journal of International Economics, 68(1), 219-237. https://doi.org/10.1016/j.jinteco.2005.06.002 
Brandt, L., Johannes, V, B., \& Zhang, Y. (2012). Creative Accounting or Creative Destruction? Firm-level Productivity Growth in Chinese Manufacturing. Journal of Development Economics, 97(2), 339-351. https://doi.org/10.1016/j.jdeveco.2011.02.002

Brandt, L., Johannes, V, B., Wang, L. H., \& Zhang, Y. F. (2017). WTO Accession and Performance of Chinese Manufacturing Firms. American Economic Review, 107(9), 2784-2820. https://doi.org/10.1257/aer.20121266

Cai, H. B., \& Liu, Q. (2009). Competition and Corporate Tax Avoidance: Evidence from Chinese Industrial Firms. Economic Journal, (537), 537. https://doi.org/10.1111/j.1468-0297.2009.02217.x

De, L. (2012). Recovering markups from production data. International Journal of Industrial Organization, 29(3), 1-355. https://doi.org/10.1016/j.ijindorg.2011.02.002

Feenstra, R. C., Li, Z. Y., \& Yu, M. J. (2011). Exports and Credit Constraints under Incomplete Information: Theory and Evidence from China. Review of Economics and Statistics, 96(4), 729-744. https://doi.org/10.1162/REST_a_00405

Ferreira, F. H. G., \& Litchfield, J. A. (1999). Calm after the Storms: Income Distribution and Welfare in Chile. World Bank Economic Review, 13(3), 509-538. https://doi.org/10.1093/wber/13.3.509

Gibson, J., Stillman, S. (nd.). Why Do Big Firms Pay Higher Wages? Evidence from an International Database. Review of Economics \& Statistics, 91(1), 213-218. https://doi.org/10.1162/rest.91.1.213

Helpman, E., \& Itskhoki, O. (2010). Labor market rigidities, trade and unemployment. Review of Economic Studies, 77(3), 1100-1137. https://doi.org/10.1111/j.1467-937X.2010.00600.x

Levinsohn, J., \& Petrin, A. (2005). Estimating Production Functions Using Inputs to Control for Un-observables. Review of Economic Studies, 70(2), 317-341. https://doi.org/10.1111/1467-937X.00246

Levinson, J. (1999). Employment Responses to International Liberalization in Chile. Journal of International Economics, (47), 321-344. https://doi.org/10.1016/S0022-1996(98)00026-9

Melitz, M. J. (2003). The impact of trade on intra-industry reallocations and aggregate industry productivity. Econometrica, 71(6), 1695-1725. https://doi.org/10.1111/1468-0262.00467

Milner, C. R., \& Wright, P. W. (1998). Modelling Labor Market Adjustment to Trade Liberalisation in an Industrializing Economy. Economic Journal, (108), 509-528. https://doi.org/10.1111/1468-0297.00301

Olley, S., \& Pakes, A. (1996). The Dynamics of Productivity in the Telecommunications Equipment Industry. Econometrica, 64(6), 1263-1297. https://doi.org/10.2307/2171831

Revenga, A. (1992). Exporting Jobs: The Impact of Import Competition on Employment and Wages in U.S. Manufacturing. Quarterly Journal of Economics, (109), 255-284. https://doi.org/10.2307/2118329

Verhoogen, E. A. (2008). Trade, Quality Upgrading, and Wage Inequality in The Mexican Manufacturing Sector. Quarterly Journal of Economics, 123(2), 489-530. https://doi.org/10.1162/qjec.2008.123.2.489

\section{Copyrights}

Copyright for this article is retained by the author(s), with first publication rights granted to the journal.

This is an open-access article distributed under the terms and conditions of the Creative Commons Attribution license (http://creativecommons.org/licenses/by/4.0/). 